\title{
Derivation and Analysis of Home Robot Care Services
}

\author{
Joo Hyun Park ${ }^{1}$ and Han Young Ryoo ${ }^{2 *}$ \\ Dept. of Content Convergence, Ewha Womans University, Korea \\ 1joohpark@ewha.ac.kr, ${ }^{2}$ hyryoo@ewha.ac.kr
}

\begin{abstract}
As the demand for home robot increases to have a convenient and relaxed life at home, enterprises are developing home robots competitively. The home robots that are currently in the market provide various services such as offering daily life information, monitoring, or communications. Especially with the increase in the number of single households and the aging population, the consumer's needs have been also changing to spotlight the care services that look after the user. So, this research was to verify what kinds of home robot services that the users prefer. In order to do so, the home robot care services were classified as into four services, which are baby care, pet care, silver care and home care, and their detailed functions were organized. Also, a survey was conducted to investigate the preferences for the home robot care services. For in-depth analysis, the care services and functions were analyzed by each user type. This research is significant because the user's cognition on the home robot care services has been systematically examined which can be used as a foundation for the enterprises to develop the home robot care services.
\end{abstract}

Keywords: Home robot, Care service, Home robot service, User preference

\section{Introduction}

The development and studies on the home robots are being actively conducted these days. The home robot can control many of the home appliances as well as providing personalized services based on the captured user's life pattern. It is also drawing attention in the aspect that the home robot can naturally interact with human beings in everyday life and fulfill the human's emotional satisfaction. The recent increased number of single households, the social change by the entry of the aging society, and the changes in the consumer's needs, such as more and more people pursuing a relaxed lifestyle and the increased importance of the leisure time, only reinforce the importance of the necessity of the home robot [1][2][3]. Although the home robot provides various services such as offering daily life information, monitoring, and communications, those care services for the user are being spotlighted [4][5]. As mentioned earlier, with the increasing number of single households, the aging society, and the change in the consumer's needs, the users demand to be in someone's care. Such change strengthens the meaning as the home robot takes the supporting role in the human's daily life [6][7]. In this research, the home robot care services are to be typed and to examine the user's cognition on the care services. In order to do so, first, the home robot care services were typed and their detailed functions were organized. Then, the users were divided into eight different groups to conduct a preference survey on the care service functions.

Article history:

Received (October 9, 2019), Review Result (November 27, 2019), Accepted (January 8, 2020) 


\section{Home robot care service derivation}

Through the case studies on the home robots that are being presented in the market, the four care services of baby care, pet care, silver care and home care have been derived.

The concepts of the four care services are as follows. The baby care service is the service provided by the home robot to take care of the baby while the pet care service is to help take care of the pet. The silver care service is to manage the elderly daily life and health. The home care service is to support on the house appliances or environment. Lastly, the security service is to manage and maintain the house safely. The security service could be included in the home care services. However, it was separated because there are home robots that are specialized for security with various detailed functions.

The detailed functions of the four care services are as follows. The functions for baby care are baby monitoring, sleep state change notification, sleep disturbance factor notification, sleep analysis, and baby soothing. For pet care services, the main functions include pet monitoring, noise detection notification, video recording when noise detected, and pet soothing. The functions for silver care services would conducting a conversation, setting the dosing time and notification, contacting the trustee in emergency, and answering the children's contact and suggesting to contact them. The home care services include home appliances control, IoT hub, house environmental management, branch registration and automatic patrol, and video recording when danger detected.

\section{Home robot care service survey}

\subsection{Introduction}

In order to understand the user's cognition on the home robot care service, a survey was conducted. The user types were divided to examine user's thorough opinions, with reference to the user types in the studies of Park \& Ryoo. The total of eight user types include male single household, female single household, male with small children, working mom with small children, housewife with small children, male with grownup children, working mom with grownup children and housewife with grownup children [8].

The five-point Likert scale was used in the survey of the home robot care service. The participants were requested to evaluate each care service. The total of 572 participants took part to include 84 male, 84 female, 96 male with small children, 53 working moms with small children, 59 housewives with small children, 85 male with grownup children, 54 working moms with grownup children, and 57 housewives with grownup children.

\subsection{Results}

\subsubsection{Intention to use care service}

The evaluation results of the intention to use the baby care service, the pet care service, the silver care service, the home care service, and the security service are as in the following [Table 1].

From the evaluation results of the intention to use the service by all respondents, the average values were highest in the order of the home care service, the silver care service, the baby care service and the pet care service. The average values of the every user type by service type are organized as follows. 
For the baby care service, it showed higher average values with the female participants with children. The housewives with small children had the highest average value and the working moms with small children and the working moms with grown up children.

Table 1. Evaluation results of the intention to use care service

\begin{tabular}{|c|c|c|c|c|}
\hline & Baby care & Pet care & Silver care & Home care \\
\hline Total & 3.59 & 3.42 & 3.94 & 3.94 \\
\hline Male single household & 3.43 & 3.43 & 3.80 & 3.80 \\
\hline Female single household & 3.63 & 3.71 & 3.90 & 4.02 \\
\hline $\begin{array}{c}\text { Male with small children } \\
\text { Housewife with small } \\
\text { children }\end{array}$ & 3.54 & 3.29 & 3.76 & 3.85 \\
\hline $\begin{array}{c}\text { Working mom with small } \\
\text { children }\end{array}$ & 3.88 & 3.34 & 4.02 & 3.96 \\
\hline $\begin{array}{c}\text { Male with grownup children } \\
\text { Housewife with grownup } \\
\text { children }\end{array}$ & 3.39 & 3.43 & 3.96 & 3.91 \\
\hline $\begin{array}{c}\text { Working mom with grownup } \\
\text { children }\end{array}$ & 3.74 & 3.46 & 4.11 & 3.98 \\
\hline
\end{tabular}

For the pet care service, the female single households had the highest average value and the working moms with grownup children and the housewives with grownup children to follow next.

For the silver care service, those who have children showed relatively higher average values in the order of the working moms with grownup children, the housewives with grownup children, the housewives with small children, the working moms with small children and the male with grownup children to rank from the highest to the lowest.

For the home care service, most of the user types had fairly high average values. It was the highest for the single households and the working moms with grownup children and the next was male with small children, male with grownup children and then the housewives with small children. For the home care service, the average value for the innovators was the highest and the working moms with grownup children, the male with small children and the female single households were followed.

\subsubsection{Baby care}

The preference survey results of the five functions of the baby care service, which are baby monitoring, notification of sleep state change, notification of sleep disturbance factor, sleep analysis and baby soothing, are organized as in the following [Table 2].

The evaluation results of the five functions for baby care show that the average values were highest in the order of the baby monitoring, the notification of sleep state change, the notification of sleep disturbance factor, the baby soothing, and the sleep analysis. The average values of the grouped user type by function are organized as follows.

The average value of the housewives with small children was highest in the baby monitoring function and then the working moms with grownup children and the housewives with small children next. 
Table 2. Evaluation results for baby care service

\begin{tabular}{|c|c|c|c|c|c|}
\hline & $\begin{array}{c}\text { Baby } \\
\text { monitoring }\end{array}$ & $\begin{array}{c}\text { Notification of } \\
\text { sleep state } \\
\text { change }\end{array}$ & $\begin{array}{c}\text { Notification of } \\
\text { sleep } \\
\text { disturbance } \\
\text { factor }\end{array}$ & Sleep analysis & Baby soothing \\
\hline Total & 3.79 & 3.78 & 3.69 & 3.62 & 3.69 \\
\hline Male single household & 3.70 & 3.69 & 3.70 & 3.63 & 3.54 \\
\hline Female single household & 3.83 & 3.81 & 3.73 & 3.61 & 3.64 \\
\hline \begin{tabular}{c} 
Male with small children \\
\hline $\begin{array}{c}\text { Housewife with small } \\
\text { children }\end{array}$
\end{tabular} & 3.65 & 3.68 & 3.54 & 3.45 & 3.44 \\
\hline $\begin{array}{c}\text { Working mom with small } \\
\text { children }\end{array}$ & 3.91 & 3.92 & 3.75 & 3.74 & 3.64 \\
\hline $\begin{array}{c}\text { Male with grownup } \\
\text { children }\end{array}$ & 3.74 & 3.74 & 3.62 & 3.56 & 3.76 \\
\hline $\begin{array}{c}\text { Housewife with grownup } \\
\text { children }\end{array}$ & 3.74 & 3.72 & 3.63 & 3.56 & 3.81 \\
\hline $\begin{array}{c}\text { Working mom with } \\
\text { grownup children }\end{array}$ & 3.94 & 3.89 & 3.81 & 3.69 & 3.93 \\
\hline
\end{tabular}

For the notification of sleep state change function, the housewives with small children and the working moms with small children shared the same highest average value. Then the working moms with grownup children and the female single households followed next.

For the notification of sleep disturbance factor function, the average value of the housewives with small children was the highest, and the second and third highest were the working moms with grownup children and the working moms with small children respectively.

For the sleep analysis function, the average value of the housewives with small children again ranked the highest followed by the working moms with small children.

For the baby soothing function, the housewives with small children had the highest average value one more time, and then the working moms with grownup children and the housewives with grownup children were next.

\subsubsection{Pet care}

The preference survey results of the four functions of the pet care service, which are pet monitoring, notification of noise detection, video recording when noise detected, and pet soothing, are organized as in [Table 3] below.

The evaluation results of the five functions of the pet care service show that the average values were highest in the order of the video recording when noise detected, the pet monitoring, the notification of noise detection and the pet soothing. The average values of the divided user type by function are organized as the following.

For the pet monitoring function, most of the user type had relatively high average values with the female single households the highest. The working moms with grownup children, the working moms with small children and the housewives with grownup children were followed next. 
Table 3. Evaluation results for pet care service

\begin{tabular}{|c|c|c|c|c|}
\hline Total & Pet Monitoring & $\begin{array}{c}\text { Notification of } \\
\text { noise detection }\end{array}$ & $\begin{array}{c}\text { Video recording } \\
\text { when noise } \\
\text { detected }\end{array}$ & Pet soothing \\
\hline Male single household & 3.53 & 3.51 & 3.55 & 3.46 \\
\hline $\begin{array}{c}\text { Female single household } \\
\text { Male with small children }\end{array}$ & 3.82 & 3.49 & 3.58 & 3.36 \\
\hline $\begin{array}{c}\text { Housewife with small } \\
\text { children }\end{array}$ & 3.36 & 3.74 & 3.75 & 3.24 \\
\hline $\begin{array}{c}\text { Working mom with small } \\
\text { children }\end{array}$ & 3.62 & 3.29 & 3.53 & 3.53 \\
\hline $\begin{array}{c}\text { Male with grownup } \\
\text { children }\end{array}$ & 3.32 & 3.51 & 3.55 & 3.38 \\
\hline $\begin{array}{c}\text { Housewife with grownup } \\
\text { children }\end{array}$ & 3.60 & 3.32 & 3.47 & 3.56 \\
\hline $\begin{array}{c}\text { Working mom with } \\
\text { grownup children }\end{array}$ & 3.63 & 3.61 & 3.61 & 3.65 \\
\hline
\end{tabular}

For the notification of noise detection function, the female single households had the highest average value and the working moms with grownup children and the working moms with small children were the second and third highest, respectively.

For the video recording function when noise detected, again, the female single households had the highest average value followed by the housewives with grownup children and the male single households.

For the pet soothing function, the working moms with grownup children showed the highest average value followed by the housewives with small children, the female single households and the housewives with grownup children.

\subsubsection{Silver care}

The preference survey results of the four functions of the silver care service, which are conducting a conversation, setting the dosing time and notification, contacting the trustee in emergency and answering the children's contact and/or suggesting to contact them, are organized as in [Table 4] below.

The evaluation results of the four functions of the silver care show that the average values were highest in the order of contacting the trustee in an emergency, setting the dosing time and notification, answering the children's contact and/or suggesting to contact them, and conducting a conversation. The average values of the divided user type by function are summarized as the following.

For conducting a conversation function, the working moms with grownup children had the highest average value and he housewives with grownup children, and the housewives with small children followed next.

For the setting the dosing time and notification, the average value was highest with the working moms with grownup children followed by the housewives with grownup children, and the working moms with small children. 
Table 4. Evaluation results for silver care service

\begin{tabular}{|c|c|c|c|c|}
\hline & $\begin{array}{c}\text { Conducting a } \\
\text { conversation }\end{array}$ & $\begin{array}{c}\text { Setting the dosing } \\
\text { time and } \\
\text { notification }\end{array}$ & $\begin{array}{c}\text { Contacting the } \\
\text { trustee in } \\
\text { emergency }\end{array}$ & $\begin{array}{c}\text { Answering the } \\
\text { children's contact } \\
\text { and suggesting to } \\
\text { contact them }\end{array}$ \\
\hline Total & 3.66 & 4.24 & 4.44 & 3.99 \\
\hline Male single household & 3.52 & 4.05 & 4.27 & 4.01 \\
\hline Female single household & 3.43 & 4.29 & 4.58 & 3.86 \\
\hline $\begin{array}{c}\text { Male with small children } \\
\text { Housewife with small } \\
\text { children }\end{array}$ & 3.45 & 4.22 & 4.40 & 4.10 \\
\hline $\begin{array}{c}\text { Working mom with small } \\
\text { children }\end{array}$ & 3.66 & 4.29 & 4.53 & 3.96 \\
\hline $\begin{array}{c}\text { Male with grownup } \\
\text { children }\end{array}$ & 3.74 & 4.32 & 4.38 & 4.09 \\
\hline $\begin{array}{c}\text { Housewife with grownup } \\
\text { children }\end{array}$ & 3.98 & 4.16 & 4.31 & 4.20 \\
\hline $\begin{array}{c}\text { Working mom with } \\
\text { grownup children }\end{array}$ & 4.06 & 4.33 & 4.43 & 4.65 \\
\hline
\end{tabular}

For contacting the trustee in emergency function, working moms with grownup had the highest average value and then the female single households and the housewives with small children were the next to follow.

For the function of answering the children's contact and/or suggesting to contact them, the average value was highest with the working moms with grownup children, and then the working moms with small children, the housewives with small children, and the housewives with grownup children followed next.

\subsubsection{Home care}

The preference survey results of the five functions of the home care service, which are home appliances control, IoT hub, house environmental management, branch registration and automatic patrol, and video recording when danger detected, are organized as in the following [Table 5].

The evaluation results of the five home care functions by all participants indicate that the average values were highest in the order of video recording when danger detected, branch registration and automatic patrol, the house environmental management, the home appliances control, and the IoT hub. The average values of the grouped user type by function are summarized as below.

For the home appliances control function, the female single households had the highest average value and the working mom with grownup children and the housewives with grownup children followed next.

For IoT hub function, again, the female single households showed the highest average value followed by the male with small children, the housewives with grownup children and the male single households. 
For the house environmental management function, the housewives with grownup children had the highest average value. Then the female single households, the housewives with grownup children, and the working mom with small children were followed.

Table 5. Evaluation results for home care service

\begin{tabular}{|c|c|c|c|c|c|}
\hline & $\begin{array}{c}\text { Home } \\
\text { appliances } \\
\text { control } \\
\end{array}$ & IoT hub & $\begin{array}{c}\text { House } \\
\text { environmental } \\
\text { management }\end{array}$ & $\begin{array}{c}\text { Branch } \\
\text { registration and } \\
\text { automatic patrol }\end{array}$ & $\begin{array}{c}\text { Video recording } \\
\text { when danger } \\
\text { detected }\end{array}$ \\
\hline Total & 3.95 & 3.87 & 4.00 & 4.01 & 4.29 \\
\hline Male single household & 3.81 & 3.75 & 3.89 & 3.76 & 4.02 \\
\hline Female single household & 4.14 & 4.04 & 4.11 & 4.02 & 4.40 \\
\hline Male with small children & 3.90 & 3.92 & 4.03 & 4.01 & 4.30 \\
\hline $\begin{array}{l}\text { Housewife with small } \\
\text { children }\end{array}$ & 3.95 & 3.81 & 3.92 & 4.19 & 4.39 \\
\hline $\begin{array}{c}\text { Working mom with small } \\
\text { children }\end{array}$ & 3.89 & 3.81 & 3.98 & 4.09 & 4.30 \\
\hline $\begin{array}{l}\text { Male with grownup } \\
\text { children }\end{array}$ & 3.92 & 3.84 & 3.87 & 3.96 & 4.26 \\
\hline $\begin{array}{c}\text { Housewife with grownup } \\
\text { children }\end{array}$ & 4.00 & 3.88 & 4.09 & 4.02 & 4.28 \\
\hline $\begin{array}{l}\text { Working mom with } \\
\text { grownup children }\end{array}$ & 4.04 & 3.83 & 4.17 & 4.19 & 4.48 \\
\hline
\end{tabular}

For the branch registration and automatic patrol function, the average value was highest with the working moms with grownup children and the housewives with small children. The next highest user type was the working moms with small children, female single households, and the housewives with grownup children.

For the video recording function when danger detected, the working moms with grownup children had the highest average value. The female single households and the housewives with small children followed next.

\section{Conclusion}

This research was to examine the user's preference of the home robot care services. To do so, the home robot care services were categorized into four different services, which are baby care, pet care, silver care and home care, and their detailed functions were organized by the user type. Next, a survey was conducted in order to check the preferences of the care service functions. Then, the intention to use the care services and the preferences of their functions were analyzed by user type. As a result, the home care service had the highest intention to use; it was analyzed that the home care service was the most demanded because most of the users are in need of it unlike the baby care, the pet care or the silver care that are limited to a certain group of people.

The preferences of the baby care functions were most popular by the female with children. This is because females still take a major role compared to the male when it comes to infant care. 
For the preferences of the pet care functions, the female single households had the highest value while the male with children had the lowest value in general. This can be interpreted that like the baby care, the female takes a big part of taking care of the pets.

Especially, the monitoring function was highly evaluated in both the baby care and pet care services; this is analyzed that the users want to constantly observe and manage the babies and the pets not only within the house but also from outside.

For the preferences of the silver care functions, the female had the highest values and the function of contacting the trustee in an emergency was highly evaluated. It can be interpreted as that the need of the functions to manage their parents is high.

The preferences of the home care functions were highest for the female single households and the female with children and they evaluated most of the functions high. Especially for the female single households, they evaluated the home care services highly because they live alone and they are very much interested in safety and security. Moreover, the female with children highly evaluated the home care services due to the high needs of a function to manage the house.

In general, the female had higher preferences of the care services than the male. Therefore, it is certainly necessary to consider the female when planning and developing the home robot care services. Especially the enterprises should plan and develop the services depending on the consumer's target.

This research is significant in the sense that a survey was conducted to verify the user's preferences of the home robot care services and the user's cognition and opinions were systematically analyzed. The results from this research can be utilized in the development and evaluation of the home robot care services.

\section{References}

[1] M. Choi and S. Kim, "A study on the role of social robot in aspect of user experiences: Focus on single person households," Journal of Digital Convergence, vol.15, no.2, pp.295-300, (2017)

[2] K. Kim, J. Choi and E. Hwang, "Social Robot Technology Trend and Industry Outlook," KEIT PD Issue Report, vol.16, no.9, pp.31-44, (2018)

[3] J. H. Park and H. Y. Ryoo, "User expectation values for smart home robot services," The Asian International Journal of Life Sciences, vol.15, no.4, pp.2871-2884, (2018)

[4] D. Lee, "Home Service Robot," Korea Industrial Technology Association, Technology \& Innovation, vol.7, pp.19-22, (2018)

[5] J. Seo, "Latest technology and standard trend of intelligent robot," KATS Technical Report, no.95, pp.1-20, (2017)

[6] W. K. Kwon and H. T. Kim, "Study on the actual use of intelligent robot," Posri Issue Report, vol.5, pp. 1-16, (2017)

[7] H. Nam, 4th Industrial Revolution and Robot Technology and Standardization Trend, ITFIND, vol.1823, pp. 2-13, (2017)

[8] J. H. Park and H. Y. Ryoo, "User Perception of the Home Robot Price," International Journal of Advanced Science and Technology, vol.115, pp. 87-98, (2018) 